\title{
Pengaruh Penerapan Online Project Based Learning Dan Berpikir Kreatif Terhadap Keterampilan Proses Sains Siswa Kelas IV Pada Pelajaran IPA
}

\author{
Nurjanah*, Ucu Cahyana, Nurjanah \\ Program Studi Pendidikan Dasar, Universitas Negeri Jakarta, Indonesia \\ *Email: nurjanah_7526140709@,mhs.unj.ac.id
}

\begin{tabular}{|c|c|}
\hline Informasi & bstrak \\
\hline $\begin{array}{l}\text { Kata kunci: } \\
\text { Online project- } \\
\text { based learning, } \\
\text { Berpikir kritis, } \\
\text { Keterampilan } \\
\text { proses sains. }\end{array}$ & $\begin{array}{l}\text { Penelitian ini bertujuan untuk mengetahui pengaruh penerapan online project-based } \\
\text { learning dan berpikir kreatif terhadap keterampilan proses sains siswa kelas IV di SD } \\
\text { Nasional } 1 \text { Kota Bekasi. Jenis penelitian eksperimen (quasi experimental design) dengan } \\
\text { desain treatment by level 2x2. Teknik pengumpulan data dilakukan dengan tes dan } \\
\text { dianalisis menggunakan analisis varians (ANAVA) dua jalan. Hasil penelitian ini } \\
\text { menunjukkan bahwa } 1 \text { ) Terdapat perbedaan hasil keterampilan proses sains kelompok } \\
\text { siswa yang menggunakan online project based learning dengan hasil keterampilan proses } \\
\text { sains kelompok siswa menggunakan penugasan konvensional } 2 \text { ) Terdapat perbedaan } \\
\text { keterampilan proses sains yang menggunakan pembelajaran online project based learming } \\
\text { dan penugasan konvensional pada kelompok siswa berpikir kreatif tinggi 3) Terdapat } \\
\text { perbedaan keterampilan proses sains yang menggunakan pembelajaran online project } \\
\text { based learning dan penugasan konvensional pada kelompok siswa berpikir kreatif rendah } \\
\text { 4) Terdapat pengaruh interaksi antara pembelajaran melalui online project based learning } \\
\text { dan berpikir kreatif terhadap keterampilan proses sains siswa sekolah dasar. Hasil } \\
\text { pengujian anava diperoleh nilai } \mathrm{F}_{\text {hitung }}=5,63 \text { dan nilai kritik } \mathrm{F}_{\text {tabel }}=3,98 \text { dengan dk } \\
\text { (1,68) pada tarafá }=0,05 \text { dengan demikian, kedua faktor tersebut tidak dapat diabaikan } \\
\text { karena saling berinteraksi satu dengan yang lainnya. }\end{array}$ \\
\hline \multirow{2}{*}{$\begin{array}{l}\text { Dipubikasikan: } \\
\text { 26-02-2021 }\end{array}$} & Abstract \\
\hline & $\begin{array}{l}\text { This research aimed to know the effect of applying online project-based learning and } \\
\text { thinking creative toward students' science process skills of class four in natural science } \\
\text { lesson at the national elementary school of Bekasi city } 1 \text {. The type of this research is an } \\
\text { experiment (quasi-experimental design) with the design of treatment by level } 2 \times 2 \text {. The } \\
\text { data technique used the test and two-way variance analysis (ANAVA). The result of this } \\
\text { research shows that } 1 \text { ) there are different results of students' science process skills using } \\
\text { the conventional assignment. 2) There is a difference between science process skill that } \\
\text { use online project-based learning and conventional assignment at student's group that } \\
\text { has high creative thinking. 3) There are differences between science process skill that } \\
\text { used online project-based learning and conventional assignment at student's group that } \\
\text { has low creative thinking. 4) There is the effect of interaction between online project- } \\
\text { based learning and thinking creative toward students' science process skill of elementary } \\
\text { school. The result of ANOVA Test is } F_{\text {count }}=5,63 \text { and the result of critic Ftabel = 3,98 } \\
\text { with dk }(1,68 \text { ) at level a }=0,05 \text {. Both of the factors can't be ignored because both are } \\
\text { interacting with each other. }\end{array}$ \\
\hline
\end{tabular}




\section{PENDAHULUAN}

Permendikbud No. 21 tahun 2016 tentang Standar Isi memberikan pengertian bahwa Ilmu Pengetahuan Alam berkaitan dengan cara mencari tahu tentang alam secara sistematis, sehingga IPA bukan hanya penguasaan kumpulan pengetahuan yang berupa fakta-fakta, konsep-konsep, atau prinsip-prinsip saja tetapi juga merupakan suatu proses penemuan (Nasional, 2016). Charlotte menulis misi mendasar dari sains adalah menyiapkan para siswa untuk hidup dalam masyarakat yang berbudaya (Sulthon, 2021). Caranya adalah menyingkapkan bagi mereka keindahan dan kekuatan dari alam yang mereka tinggali dan memperkenalkan metode-metode untuk menambah pengetahuan kita tentang semesta. Pendidikan sains di sekolah bukan dimaksudkan untuk menyiapkan anak bagi pekerjaan-pekerjaan tertentu, melainkan anak agar memperoleh bekal hidup yang berbudaya (Rachmadtullah et al., 2020).

Disini, siswa diharapkan dapat memiliki kemampuan mengamati, berpikir, menganalisa, menyimpulkan, dan mengomunikasikan yang semuanya terangkum dalam keterampilan yang harus dikuasai oleh siswa dalam pembelajaran sains, yaitu keterampilan proses sains (Sari et al., 2020). Keterampilan proses sains merupakan kemampuan dasar yang diharapkan dikuasai oleh siswa dalam pembelajaran IPA. keterampilan tersebut merupakan bagian yang membentuk landasan untuk menerapkan metode ilmiah (Khasanah et al., 2020). Fakta yang disampaikan oleh Kemendikbud, Desember 2016, bahwa berdasarkan data dari survey PISA (Programme for International Student Assesment) sebenarnya ada peningkatan pencapaian pendidikan pada tahun 2015 jika dibandingkan dengan pencapaian tahun 2012 (Hawa \& Putra, 2018). Namun capaian tersebut masih berada di bawah rata rata negara OECD (Organisation for Economic Cooperation and Development) sehingga masih perlu ditingkatkan keterampilan proses sains siswa dengan perbaikan dan perubahan berbagai metode, teknik, dan penyampaian pelajaran.

Dengan meningkatkan keterampilan proses sains dimana siswa dituntut untuk dapat menyelesaikan masalah ilmiah sehingga merangsang siswa untuk mengembangkan kemampuan berpikirnya. Diharapkan kemampuan berpikir siswa pun akan meningkat, yaitu kemampuan berpikir kreatif (HARSANTI, 2018; LISTYOWATI, 2018). Seiring dengan proses peningkatan kualitas pembelajaran yang mengutamakan nilai karakter dalan kurikulum 2013 serta metode pembelajaran yang tepat, yang diharapkan siswa dapat mengembangkan kemampuan berpikir kreatif melalui kegiatan mengamati, menanya, mencoba, mengolah, menalar, mencipta, dan mengomunikasikan.

Pembelajaran melalui online project based learning merupakan model pembelajaran jarak jauh yang bisa menjadi alternatif pembelajaran di saat guru tidak bisa bertatap muka dengan siswanya. Upaya untuk mengajak siswa lebih dekat dengan sumber belajar yang sesungguhnya, yaitu alam dan masyarakat. Model pembelajaran melalui online projectbased learning merupakan upaya mengarahkan siswa untuk melakukan aktivitas yang bisa membawa mereka pada perubahan perilaku terhadap lingkungan, dan juga perubahan perilaku dalam mengomunikasikan (Setiawan, 2015; Setiawan et al., 2020).

Pada dasarnya keterampilan seseorang tergantung juga kepada cara berpikir seseorang itu. Semakin kreatif cara berpikir seseorang, maka keterampilan yang dimiliki orang tersebut akan semakin baik. Menurut 
teori yang ada, kreativitas seseorang lah yang membedakan maju mundurnya seseorang dalam kehidupan ini.

Peran guru dalam mencari dan menggunakan model pembelajaran yang tepat dibutuhkan untuk merangsang kreativitas anak dalam berpikir. Berpikir kreatif sangat diperlukan bagi siswa untuk mendapatkan hasil yang baik dan berpikir kreatif memerlukan faktor pendukung. Model yang tepat sangat diperlukan bagi anak untuk merangsang siswa berpikir kreatif. Salah satu model yang dapat meningkatkan kreativitas berpikir siswa adalah model penugasan. Usman (1993) menyatakan bahwa penugasan adalah suatu cara penyajian pelajaran dengan cara guru memberi tugas tertentu kepada siswa dalam waktu yang telah ditentukan dan siswa mempertanggung jawabkan tugas yang dibebankan kepadanya. Berdasarkan hal tersebut yang menjadi dasar peneliti menggunakan treatment pembelajaran melalui online project based learning adalah bahwa model tersebut dapat meningkatkan kreativitas dan keterampilan siswa. Hal inilah yang membuat peneliti menggunakan model pembelajaran melalui online project based learning untuk memberikan pengaruh terhadap keterampilan siswa dalam sains.

Berpikir merupakan aktivitas mental yang dilakukan seseorang sebagai reaksi atas isu atau fenomena yang berkembang. Proses berpikir ini terjadi di dalam otak dan pikiran manusia sebagai individu yang bekerja baik secara pasif, aktif, maupun masif. Berpikir kreatif secara sederhana merupakan keterampilan atau kemampuan atau kompetensi individu terkait bagaimana ia mampu menciptakan, memanipulasi, mendiferensiasi suatu hal yang membawa manfaat dalam kehidupan.

Definisi yang paling umum dari sains natural science" atau sering disebut juga dengan "science". Natural berarti alamiah, berhubungan dengan alam. Sedangkan science artinya ilmu pengetahuan. Menurut Olivia (2008) menyatakan bahwa science atau sains mengandung arti ilmu pengetahuan dalam pengertian yang amat luas meliputi pengetahuan tentang kehidupan, makhluk hidup, alam semesta, serta hubungan antarmanusia itu sendiri. Juhji (2016) berpedapat bahwa sains berupa pengetahuan rasionalan objektif.

Sedangkan keterampilan menurut Syah (2007) adalah kemampuan yang dimiliki untuk melakukan pola-pola tingkah laku kompleks dan tersusun rapi secara teratur dan sesuai keadaan untuk mencapai hasil tertentu. Usman (2004) menyatakan bahwa keterampilan proses merupakan pendekatan pembelajaran yang merujuk pada optimalisasi kemampuan mental, fisik, dan sosial. Hamalik, (2009) menyatakan bahwa keterampilan proses dalam ruang lingkup sains sebagai pengetahuan mengenai konsep dan prinsip yang didapat siswa bila dirinya mempunyai kapabilitas dasar tertentu atau dapat keterampilan proses sains yang dibutuhkan untuk menggunakan sains.

Dalam mengembangkan dan mengoptimalkan keterampilan proses, perlu dikembangkan juga sikapsikap yang mendukung proses tersebut seperti kreatif, kerjasama, bertanggung jawab, dan berdisiplin. Keterampilan proses sebagai suatu pendekatan dalam proses pembelajaran untuk mengembangkan kemampuan fisik dan mental yang mendasar pada siswa. 
Model pembelajaran berbasis proyek (project based learning) adalah sebuah model pembelajaran yang menggunakan proyek (kegiatan) sebagai inti pembelajaran. Dalam kegiatan ini, siswa melakukan eksplorasi, penilaian, interpretasi, dan sintesis informasi untuk memperoleh berbagai hasil belajar (pengetahuan, keterampilan, dan sikap). Karakteristik Model pembelajaran berbasis proyek selalu dimulai dengan menemukan apa sebenarnya pertanyaan mendasar, yang nantinya akan menjadi dasar untuk memberikan tugas proyek bagi siswa (melakukan aktivitas).

Dalam pelaksanaannya, model pembelajaran berbasis proyek memiliki langkah-langkah (sintaks) yang menjadi ciri khasnya dan membedakannya dari model pembelajaran lain seperti model pembelajaran penemuan (discovery learning mode) dan model pembelajaran berdasarkan masalah (problem based learning model). Adapun langkah-langkah itu adalah; (1) menentukan pertanyaan dasar; (2) membuat desain proyek; (3) menyusun penjadwalan; (4) memonitor kemajuan proyek; (5) penilaian hasil; (6) evaluasi pengalaman.

\section{METODE}

Penelitian ini menggunakan metode eksperimen semu (quasi experimental design) yang merupakan pengembangan dari metode eksperimen murni analisis varians (ANAVA) dengan desain treatment by level 2x2. mempunyai kelompok kontrol namun tidak dapat sepenuhnya berfungsi untuk mengontrol variabelvariabel dari luar yang mempengaruhi pelaksanaan eksperimen Sugiyono (2013). Penelitian ini dilaksanakan pada bulan juli smester ganjil tahunajaraan 2020-2021. Populasi dalam penelitian ini adalah seluruh siswa kelas IV di SD Nasional 1 Kota Bekas. Teknik pengambilan sampel menggunakan purposive sampling.

Tabel 1. Factorial design $2 \times 2$ pada penelitian ini

\begin{tabular}{clcc}
\hline & & \multicolumn{2}{c}{ Kreatif } \\
\cline { 3 - 4 } $\begin{array}{c}\text { Model } \\
\text { Pembelajaran }\end{array}$ & $\begin{array}{l}\text { Online Project } \\
\text { Based Learning }\end{array}$ & $\mathrm{A}_{1} \mathrm{~B}_{1}$ & $\mathrm{~A}_{1} \mathrm{~B}_{2}$ \\
\cline { 2 - 4 } & $\begin{array}{l}\text { Penugasan } \\
\text { konvensional }\end{array}$ & $\mathrm{A}_{2} \mathrm{~B}_{1}$ & $\mathrm{~A}_{2} \mathrm{~B}_{2}$ \\
\hline
\end{tabular}

Pengumpulan data dilakukan dengan kuesioner keterampilan proses sains, dan kemampuan berpikir kreatif oleh karena itu analisis data meliputi uji normalitas, homogenitas, varians dan hipotesis. Uji normalitas digunakan untuk mengetahui normalitas data guna menentukan uji statistik dalam uji hipotesis. Uji homogenitas untuk uji lanjut statistik parametrik yang digunakan jika data terdistribusi normal. Uji hipotesis dilakukan untuk mengetahui Pengaruh Online Project Based Lerning dan Berpikir Kreatif Terhadap Keterampilan Proses Sains.

\section{HASIL DAN PEMBAHASAN}

Hasil keterampilan proses sains siswa menggunakan online project-based learning dengan kelompok siswa menggunakan penugasan konvensional. Berdasarkan hasil perhitungan data dapat diketahui bahwa pada siswa menggunakan pembelajaran online project based learning memperoleh rata-rata nilai sebesar 75,93 sedangkan hasil keterampilan proses sains menggunakan penugasan konvensional memperoleh rata-rata 71,66. Hasil analisis varians untuk kedua pendekatan pembelajaran menunjukkan harga $F_{\text {hitung }}$ sebesar 5,10 
lebih besar dari harga Ftabel sebesar 3,98 pada taraf signifikan $\alpha=0,05$ hal ini disebabkan karena pembelajaran dengan menggunakan model online project based learning mampu meningkatkan keaktifan siswa, berpikir kritis dan keterampilan intelektual. Tidak seperti model pembelajaran yang berpusat pada guru (teacher centered) sehingga sangat tepat untuk digunakan dalam proses pembelajaran. Dengan kata lain, project based learning merupakan strategi untuk mengonstruksi atau menumbuhkan kompetensi tertentu dengan menggunakan projek sebagai stimulus sekaligus fokus aktivitas belajar si pembelajar. Siswa juga dapat mengembangkan keterampilan, berpikir kritis lalu mengaplikasikan pengetahuan untuk membuat sebuah project yang akan memecahkan masalah yang disajikan.

Hasil keterampilan proses sainns siswa memiliki kemampuan berpikir kreatif tinggi memperoleh ratarata sebesar 73,83 dan siswa yang memiliki kemampuan berpikir kreatif rendah memperoleh rata-rata sebesar 70,66 Hasil analisis varians untuk kedua pendekatan kemampuan berpikir kreatif menunjukkan

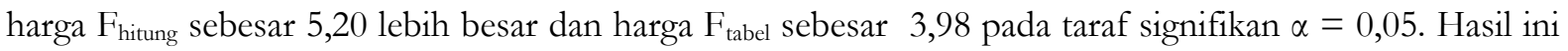
terjadi karena pelaksanaan pembelajaran dipengaruhi berbagai faktor terutama dalam diri siswa sendiri terkait dengan kemampuan berpikir baik kemampuan berpikir kreatif tinggi maupun kemampuan berpikir kreatif rendah. Karena berpikir merupakan aktivitas mental yang dilakukan seseorang sebagai reaksi atas isu atau fenomena yang berkembang. Weisberg (2006) mengartikan berpikir kreatif mengacu pada prosesproses untuk menghasilkan suatu produk kreatif yang merupakan karya baru (inovatif) yang diperoleh dari suatu aktivitas/kegiatan yang terarah sesuai tujuan. Berdasarkan hal tersebut maka setiap orang memiliki kemampuan berpikirnya masing-masing. Pengenalan kemampuan berpikir sangat penting bagi guru dengan mengetahui kemampuan berpikir kreatif belajar tiap siswa maka guru dapat menerapkan strategi atau model yang tepat baik dalam pembelajaran maupun dalam pengembangan diri.

Hasil keterampilan proses sains kelompok yang memiliki kemampuan berpikir kreatif tinggi menggunakan Online Project Based lebih tinggi dibandingan dengan kelompok siswa yang memiliki kemampuan berpikir kreatif rendah menggunakan model Online Project Based. Hasil keterampilan proses sains kelompok siswa menggunakan model Online Project Based Learning dengan berpikir kreatif tinggi sebesar 82,88 dengan nilai Lo $=0,164$ sedangkan Lt $=0,206$ pada taraf signifikan $\alpha=0,05$ Dengan dernikian Lo $<$ Lt, dan siswa menggunakan model Online Project Based Learning dengan kemampuan berpikir kreatif rendah memperoleh rata-rata sebesar 74,3. dengan nilai $L o=0,191$ sedangkan $L t=0,213$ pada taraf signifikan $\alpha=$ 0,05 Dengan demikian Lo < Lt. Kemampuan berpikir kreatif adalah hasil interaksi antara individu dan lingkungannya. Seseorang mempengaruhi dan dipengaruhi oleh lingkungan di mana ia berada, dengan demikian baik perubahan di dalam individu maupun di dalam lingkungan dapat menunjang atau menghambat kemampuan berpikir kreatif. Implikasinya adalah bahwa kemampuan berpikir kreatif dapat ditingkatkan melalui proses pembelajaran. berpikir kreatif dapat ditingkatkan melalui proses pembelajaran.

Kreativitas akan terus berkembang menyesuaikan dengan stimulus-stimulus yang ada di lingkungan sekitarnya. Selama berinteraksi dengan lingkungan itulah, kemampuan berpikir divergen yang merupakan ciri utama kreativitas dapat berkembang karena menghadapi persoalan yang ada di lingkungan. Sehingga, 
faktor dari diri sendiri dan faktor lingkungan merupakan beberapa faktor yang mempengaruhi perbedaan dari kemampuan berpikir kreatif siswa.

Hasil keterampilan proses sains kelompok siswa yang memiliki kemampuan berpikir kreatif tinggi menggunakan penugasan konvensional lebih tinggi dengan nilai rata-rata 76,33 nilai Lo $=0,167$ sedangkan $\mathrm{Lt}=0,213$ pada taraf signifikan $\alpha=0,05$ dengan demikian Lo $<\mathrm{Lt}$ dibandingan dengan kelompok siswa yang memiliki kemampuan berpikir kreatif rendah menggunakan penugasan konvensional nilai rata-rata 71,6 nilai Lo $=0,182$ sedangkan Lt $=0,213$ pada taraf signifikan $\alpha=0,05$ dengan demikian Lo $<$ Lt. Ujang Sukandi (2003), mendefenisikan bahwa pendekatan konvensional ditandai dengan guru mengajar lebih banyak mengajarkan tentang konsep-konsep bukan kompetensi, tujuannya adalah peserta didik mengetahui sesuatu bukan mampu untuk melakukan sesuatu dan pada saat proses pembelajaran peserta didik lebih banyak mendengarkan. Di sini terlihat bahwa pendekatan konvensional yang dimaksud adalah proses pembelajaran yang lebih banyak didominasi gurunya sebagai "pentransfer ilmu, sementara peserta didik lebih pasif sebagai "penerima" ilmu.

Terjadi interaksi antara model pembelajaran dengan kemampuan berpikir terhadap hasil belajar siswa pada mata pelajaran IPA. Hasil pengujian anava diperoleh nilai $\mathrm{F}_{\text {hitung }}=5,61$ dan nilai kritik $\mathrm{F}_{\text {tabel }}=3,98$ dengan $\mathrm{dk}(1,68)$ pada taraf á $=0,05$. Hasil ini menunjukkan bahwa $\mathrm{F}_{\mathrm{h}}=>\mathrm{F}_{\mathrm{t}}=$ sehingga terdapat interaksi antara penggunaan model pembelajaran dan kemampuan berpikir dalam mempengaruhi hasil keterampilan proses sains pada mata pelajaran IPA. Jika dilihat dari rata-rata hasil belajar masing-masing kelompok (Grafik pada Pada Gambar 4.9) menunjukkan bahwa rata-rata siswa yang diajar menggunakan model Online Project Based Learning untuk siswa yang memiliki kemampuan berpikir kreatif tinggi lebih tinggi dibandingkan dengan penugasan konvensional, dan siswa yang memiliki kemampuan berpikir kreatif rendah lebih tinggi menggunakan model Online Project Based Learning dibandingkan dengan siswa yang menggunakan model pembelajaran penugasan konvensional. Hal ini disebabkan bahwa dalam pembelajaran, terdapat dua faktor utama yang mempengaruhi pencapaian hasil belajar siswa, yaitu kualitas pembelajaran dan karakteristik siswa.

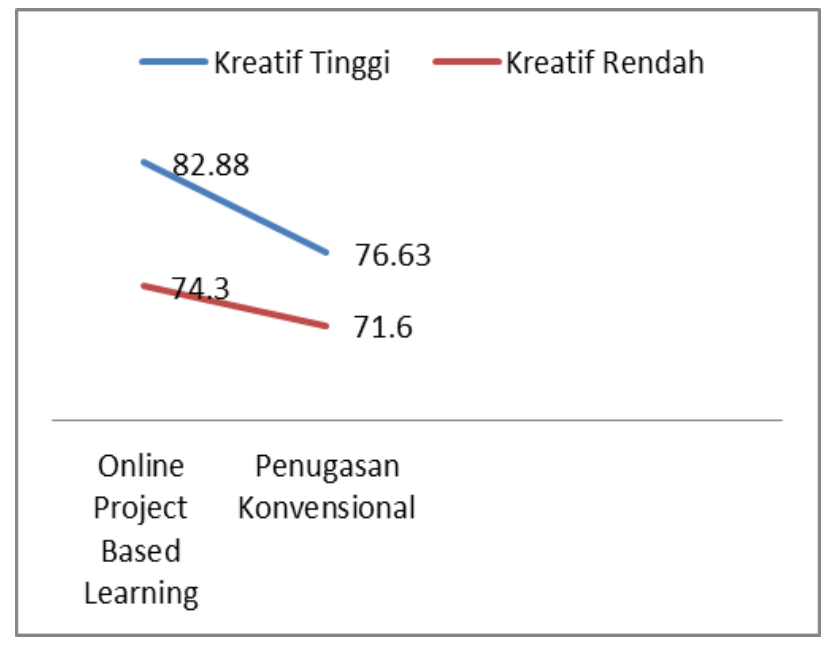

Gambar 1. Interaksi Model Pembelajaran dan Kemampuan Berpikir Kreatif Terhadap Hasil Keterampilan Proses 


\section{KESIMPULAN}

Hasil keterampilan proses sains pada mata pelajaran IPA kelompok siswa yang diajar menggunakan Online Project Based Learning lebih tinggi dibandingkan hasil keterampilan proses sains kelompok siswa yang diajar dengan menggunakan penugasan konvensional. Hasil keterampilan proses sains siswa pada mata pelajaran IPA yang memiliki kemampuan berpikir kreatif tinggi lebih tinggi dibandingkan dengan siswa yang memiliki kemampuan berpikir kreatif rendah. Hasil keterampilan proses sains kelompok yang memiliki kemampuan berpikir kreatif tinggi lebih tinggi dibandingan dengan kelompok siswa yang memiliki kemampuan berpikir kreatif rendah menggunakan model Online Project Based. Hasil keterampilan proses sains kelompok yang memiliki kemampuan berpikir kreatif tinggi lebih tinggi dibandingan dengan kelompok siswa yang memiliki kemampuan berpikir kreatif rendah menggunakan penugasan konvensional

Terjadi interaksi antara model pembelajaran dengan kemampuan berpikir terhadap hasil belajar siswa pada mata pelajaran IPA. Hasil pengujian anava diperoleh nilai $\mathrm{F}_{\text {hitung }}=5,63$ dan nilai kritik $\mathrm{F}_{\text {tabel }}=3,98$ dengan $\mathrm{dk}(1,68)$ pada taraf á $=0,05$. Hasil ini menunjukkan bahwa $\mathrm{F}_{\mathrm{h}}=>\mathrm{F}_{\mathrm{t}}=$ sehingga terdapat interaksi antara penggunaan model pembelajaran dan kemampuan berpikir dalam mempengaruhi hasil keterampilan proses sains pada mata pelajaran IPA

\section{DAFTAR PUSTAKA}

Desmita.Psikologi Perkembangan Peserta Dididk. Bandung: PT Remaja Rosdakarya, 2009

Hamalik, Oemar.Kurikulum dan Pembelajaran. Jakarta: Bumi Aksara, 2009

HARSANTI, A. G. (2018). PENGEMBANGAN PERANGKAT PEMBELAJARAN DENGAN MENGGUNAKAN OUTBOND UNTUK PENINGKATAN PERILAKU SOSIAL SISWA KELAS IV SDN 01 TAWANGREJO. Buana Pendidikan: Jurnal Fakultas Keguruan Dan Ilmu Pendidikan, 14(25 SE-), 21-29. https://doi.org/10.36456/bp.vol14.no25.a1461

Hawa, A. M., \& Putra, L. V. (2018). PISA untuk siswa Indonesia. Janacitta, 1(01).

Khasanah, N. R., Atnuri, \& Fanani, A. (2020). Pengaruh Crossword Puzzle Berbasis 4C Terhadap Hasil Belajar Ipa Sekolah Dasar. Buana Pendidikan: Jurnal Fakultas Keguruan Dan Ilmu Pendidikan, 16(30s SE), 41-48. https://doi.org/10.36456/bp.vol16.no30s.a2756

Ikhsan, Fuad.Dasar-dasar Kependidikan. Jakarta: Rineka Cipta, 2005

Juhji. "Peningkatan Keterampilan Proses Sains SIswa melalui Pendekatan Inkuiri Terbimbing”, Jurnal Penelitian dan Pembelajaran IPA Vol. 2 No. 1, Juni 2016, 58 - 70

LISTYOWATI, A. (2018). PERKULIAHAN BERBASIS LITERASI PADA MATA KULIAH KREATIVITAS DAN KEBERBAKATAN DI ANGKATAN 2016 PG PAUD UNIVERSITAS PGRI ADI BUANA SURABAYA. Buana Pendidikan: Jurnal Fakultas Keguruan Dan Ilmu Pendidikan, 14(25 SE-), 14-20. https:// doi.org/10.36456/bp.vol14.no25.a1468

Nasional, D. P. (2016). Permendikbud No. 21 Tahun 2016 Tentang Standar Isi Pendidikan Dasar Menengah. Jakarta: Depdiknas.

Olivia, Femi.Gembira Belajar dengan Mind Mapping. Jakarta: PT. Elex Media Komputindo, 2008

Rachmadtullah, R., Yustitia, V., Setiawan, B., Mahya Fanny, A., Pramulia, P., Susiloningsih, W., Tur Rosidah, C., Prastyo, D., \& Ardhian, T. (2020). The Challenge Of Elementary School Teachers To Encounter Superior Generation In The 4.0 Industrial Revolution: Study Literature. International Journal of Scientific \& Technology Research, 9(4), 1879-1882. www.ijstr.org

Sari, Y., Luvita, R. D., Cahyaningtyas, A. P., Iasha, V., \& Setiawan, B. (2020). Pengaruh Metode 
Pembelajaran Struktural Analitik Sitentik terhadap Kemampuan Menulis Permulaan di Sekolah Dasar. Jurnal Basicedu, 4(4), 1125-1133.

Setiawan, B. (2015). Eksperimentasi Model Pembelajaran Problem Solving dengan Pendekatan Peer Tutoring Berbasis Metode Pembelajaran Eksperimen dan Demonstrasi pada Materi Fluida Statis Siswa Kelas X MLA SMA Negeri 1 Banyudono.

Setiawan, B., Rachmadtullah, R., \& Iasha, V. (2020). Problem-Solving Method: The Effectiveness of The Pre-service Elementary Education Teacher Activeness in The Concept of Physics Content. Jurnal Basicedu, 4(4), 1074-1083.

Sulthon, S. (2021). Building Environmental Awareness based on Science and Technology Society among MI Students. Elementary: Jumal Ilmiah Pendidikan Dasar, 6(2), 167-182.

Susman,Kathleen M. Discovery-Based Learning In The Life Sciences. New Jersey: Wiley-Blackwell, 2015

Syah, Darwyan; Supardi dan Eneng Muslihah.Strategi Belajar Mengajar. Jakarta: Diadit Media, 2009Sugiyono.Metode Penelitian Kuantitatif, Kualitatif, dan R \& D. Bandung: Alfabeta, 2011 